\title{
Problem Issues of Implementation of the Constitutional Right to Peaceful Assembly
}

\author{
Andrii Pravdiuk ${ }^{1}$ \\ ${ }^{1}$ Vinnytsia National Agrarian University \\ 3 Sonyachna Street, Vinnytsia , 21000, Ukraine
}

DOI: $10.22178 /$ pos. $69-2$

LCC Subject Category: K3154-3370

Received 20.03.2021

Accepted 27.04.2021

Published online 30.04.2021

Corresponding Author:

a.pravd4449@gmail.com

(C) 2021 The Author. This article is licensed under a Creative Commons Attribution 4.0 License @)

\section{INTRODUCTION}

Ukraine needs to establish international and European standards referring to the right to freedom of peaceful assembly, establish appropriate national legal institutions, and build a legal civil society. Nowadays, Ukraine is experiencing qualitative changes in the field of observance of the rights of citizens to mass meetings, rallies, and demonstrations. Cases of abuse of power by officials, violation of the rights and freedoms of citizens, the use of pressure and force by law enforcement officials against participants and organizers of mass meetings are not systemic.

However, during the quarantine period caused by the COVID pandemic, respect for citizens' fundamental rights and freedoms, including the right to peaceful assembly, is especially urgent. Some governments are trying to use the COVID pandemic as a reason for strengthening their regimes, restricting democracy, and infringing on the rule of law. In such conditions, strict adherence to international standards in protecting the right to peaceful assembly is of great significance, so there is a need to improve national legislation, namely to adopt a special law on peaceful assembly. The introduction of such special regimes in the state as quarantine or emergency involves restricting fundamental human rights, including the right to peaceful assembly. Therefore, when implementing them, it is necessary to adhere to the international and constitutional norms strictly.

In addition, in Ukraine, the need to legislate the right to peaceful assembly is caused by the active decentralization processes in administrative reform. Legislation on local self-government practically does not regulate the powers of executive bodies of territorial communities in observance of the right to peaceful assembly, which causes potential risks of non-compliance with constitutional guarantees, violation of citizens' freedom of peaceful assembly. It is necessary to establish the powers of local self-government bodies at the legislative level to observe the rights to freedom of peaceful assembly of citizens at the territorial community level. 
Negative consequences of the absence of the particular law that guarantees the constitutional right of Ukrainian citizens to peaceful assembly and the gaps and shortcomings in some effective bylaws need to be addressed as soon as possible to bring national legislation into line with international standards.

The issue of constitutional and legal regulation of peaceful assemblies of citizens in Ukraine is examined in the scientific works of such researchers as 0. Vaskovska, O. Vlasenko, M. Denisova, R. Kuibida, R. Melnyk, V. Pohorilko, V. Rudenko, M. Sereda, M. Smokovych, S. Shevchuk, P. Shliakhtun, V. Fedorenko and others. However, despite many works, the problems of constitutional and legal regulation of peaceful assemblies of citizens in Ukraine are becoming greatly important, requiring further study and research to improve national legislation and bring it to international standards in the field of fundamental human and civil rights.

\section{RESULTS AND DISCUSSION}

One of the forms of direct democracy is a peaceful assembly. The right to freedom of peaceful assembly is a fundamental right of a man and citizen, which is the basis of a democratic society [12, p. 65].

Freedom of peaceful assembly in Ukraine is guaranteed by Article 39 of the Constitution of Ukraine, "Citizens have the right to assemble peacefully, without weapons and to hold meetings, rallies, marches and demonstrations having notified the executive authorities or local governments about them in advance" [9].

The right to peaceful assembly is "one of the constitutional guarantees of the right of a citizen to freedom of his worldview and religion, thought and speech, to free expression of his views and beliefs, to use and disseminate information orally, in writing or in any other way, to free development of one's personality, etc." [21].

Today, neither the legal doctrine nor the international documents and national legislation clearly defines the term "peaceful assembly". Let's consider available definitions of this concept, which most accurately reveal its legal meaning.

The meaning of the term "peaceful assembly" was explained in the report by M. Kiai, the UN Special Rapporteur on the rights to freedom of peaceful assembly and the association at the 20th session of the Human Rights Council. The Special Rapporteur has noted that a peaceful assembly is a deliberate temporary assembly in a private or public space for a specific purpose, covering demonstrations, rallies, strikes, marches, etc. [8].

According to Jeremy McBride, peaceful assembly is an individual right or ability of people to unite and collectively express, promote, persecute and defend their collective or common ideas [1, p. 19]. The author considers the right to assemble peacefully as an individual right because everyone decides to participate in a peaceful assembly. At the same time, the essence of a peaceful assembly is the ability to unite, collectively express and defend collective ideas.

According to R. Melnyk, the right to freedom of peaceful assembly is an integral part of the right to social communication, which is extremely important for a man and a citizen, because it is through him that the needs of a person and a citizen to communicate with others are realized; due to this right there can be experienced selfrealization of the person and the citizen in society and the state. We must not forget that "the man is a social being", which remains a human precisely through communication. One possible form of such communication is peaceful assembly [12, p. 59].

Scientists A. Shevchenko, M. Denisova and 0 . Denisova believe that "the right to peaceful assembly is a collective political right of an indefinite number of individuals to hold any measures and actions, which are not prohibited by the Constitution and laws of Ukraine and aimed at expressing and announcing their collective position on a particular issue or issues being of social or group importance, in the places with unrestricted, public access" [27, p. 127].

Researcher 0. Vlasenko notes that "a peaceful assembly is a collective or individual, peaceful, public event that is accessible to everyone under the participation of the citizens of Ukraine, foreigners, stateless persons who are legally on the territory of Ukraine, to form and (or) express a position on various issues of public life, attracting public attention, support, protect or protest against any decisions of state bodies, local governments, enterprises, institutions and organizations of all forms of ownership, which is conducted in the forms provided by the legislation of Ukraine using (or without) various means of visual agitation as well as loud technical means" [3, p. 8]. 
According to V. Pogorilko and V. Fedorenko, assembly of citizens is a form of direct democracy, which provides for peaceful assembly of unarmed citizens to address socially significant issues [15, p. 45].

In our opinion, the description of a peaceful assembly as a legal phenomenon that is presented in M. Sereda's scientific research is quite complete. Thus, a peaceful assembly is a conscious (meaningful) meeting of a group of people, which takes place for public expression or formulation of standard views in a specific physical place (territory, route) and peacefully takes place. In addition to the main features, the researcher notes that "there are also many optional ones that can play a supporting role in distinguishing peaceful assemblies and related phenomena (for example, having an organizer of a meeting, notification of the relevant authorities, aids for effective communication, etc.)" [24, p.75].

The Constitution of Ukraine specifies four forms of holding peaceful assemblies: meetings of citizens, rallies, marches, demonstrations. The Code of Administrative Procedure of Ukraine defines peaceful assemblies as meetings, rallies, marches, demonstrations, etc., i.e. it provides for the possibility of peaceful assemblies in other forms. There are other forms of peaceful assembly (street campaigns, pickets, etc.). It should be noted that new forms of peaceful assembly are emerging, e.g. flash mobs. Let's consider the characteristics of the most common forms of peaceful assembly. For example, Part 1 of Article 8 of the Law of Ukraine "On Local SelfGovernment in Ukraine" general meeting of citizens at the place of residence is a form of their direct participation in solving issues of local importance. Part 2 of the same Article states that the decisions of the general meeting of citizens are taken into account by local governments in their activities, and Part 3 provides that the procedure for holding a general meeting of citizens at the place of residence is determined by the law and the statute of the territorial community [6].

Rally is a mass meeting on urgent, primarily political issues [2], held, as a rule, on the streets, squares, stadiums, parks. A mass audience characterizes rallies, speeches by speakers, slogans, flags, and various appeals (oral, printed).

The demonstration is one of the forms of mass expression of political sentiment, protest, solidarity and the like by holding demonstrations, rallies, strikes, street marches, etc. [4]. The academ- ic dictionary defines a demonstration as a procession of people expressing any socio-political sentiments [2].

Picketing is a form of direct democracy implemented in the form of public expression of collective or individual opinion (demonstration of support, solidarity, protest against something) through the placement of citizens near a specific object using posters, banners and other means of visual agitation. Picket is a more local protest than a rally [16, p.153].

One of the most common forms of peaceful assembly both in the world and in Ukraine is a flash mob that is a pre-planned mass action, which usually organized via the Internet or other modern means of communication, in which a large number of people suddenly gather in a public place, perform pre-arranged actions (scenario) for a few minutes, and then quickly disperse; participants of the same event may pursue various goals, including political ones (political mob).

Typical rules of the flash mob are the prohibition against gathering or drawing attention at the place where it is organized before the action, simultaneous beginning and end of the action by its participants; after the auction, you need to instantly disappear from that place in different directions pretending that nothing has happened [25].

It should be noted that the main feature of the above-mentioned peaceful assemblies is their peace, holding without weapons and violence.

Considering the legal nature of peaceful assemblies, it should be understood that Realization of the right to peaceful assembly is closely connected with the Realization of many other fundamental human and civil rights: freedom of thought and speech, freedom of creative activity, freedom of religion, freedom of association, the right to freedom of action, freedom of movement and freedom to leave the territory of Ukraine, personal non-property rights, etc. For example, there is an extremely close link between the right to freedom of peaceful assembly and freedom of thought and speech. This is caused by the fact that peaceful assemblies are aimed at formulating a specific public position (opinion) and its collective expression. Therefore, any state measures directed against a peaceful assembly also impose restrictions on freedom of thought and speech. However, if peaceful assemblies are limited due to the content of opinions expressed 
during their holding, in this case, state measures require additional justification, as in such a situation, there is a parallel restriction of two fundamental rights (freedoms) of citizens [6, p. 61].

The problem of observance of freedom of assembly has become especially relevant in Ukraine due to numerous protests that have repeatedly taken place in Ukraine. The most massive of them is the Revolution on Granite, "Ukraine without Kuchma", the Orange Revolution, the Revolution of Dignity. It should be noted that, for example, the Revolution of Dignity was reasoned by the violation of the right to the peaceful assembly that was a violent dispersal of a peaceful protest on Independence Square in Kyiv, the main participants of which were students.

The state of judicial bans on rallies and demonstrations shows a direct dependence on peaceful assembly on the socio-political climate. According to statistics, during 2010-2012, the number of court bans on the rallies and demonstrations increased. The maximum number of bans was in 2012 (349 satisfied lawsuits out of 414 considered). In 2013, the number of restrictions began to decrease (205 satisfied out of 262 considered). After the Revolution of Dignity 2013-2014, both the number of lawsuits banning assemblies and the percentage of "prohibitive" court decisions decreased sharply. During 2016, the courts considered only 19 lawsuits banning rallies, and only 8 of them were satisfied; in 2017, 6 cases were considered, and none was satisfied; and in 2018, no case of restrictions on the exercise of the right to peaceful assembly was recorded [14, p.2-3].

Nowadays, during the COVID pandemic, respect for fundamental rights and freedoms of citizens, including the right to peaceful assembly, is especially relevant.

The United Nations Human Rights Monitoring Mission in Ukraine has prepared a report on the human rights in Ukraine during the pandemic. The report states that the Office of the United Nations High Commissioner for Human Rights "is concerned that law enforcement agencies have arbitrarily applied quarantine restrictions related to COVID-19 and that several rallies have been suspended or that administrative or criminal proceedings have been instituted against the organizers, while other rallies have been held without any obstacles" [28, p. 20].

Thus, by the Resolution of the Cabinet of Ministers of Ukraine No 211 of 11 March 2020, "On
Prevention of the Spread of COVID-19 in Ukraine", the quarantine was established throughout Ukraine, having to prohibit all mass events involving a certain number of persons except measures necessary to ensure the work of public authorities and local governments [17].

The right to freedom of peaceful assembly may be restricted "to prevent riots or crimes, protect the health of the population or protect the rights and freedoms of other people", which is enshrined in Part 2 of Article 39 of the Constitution. However, restrictions on the exercise of this right may be imposed by the court by the law and only in the interests of national security and public order.

Attention should also be paid to Article 64 of the Constitution, which provides the possibility of temporary restriction of the right to freedom of assembly, rally, march, and demonstration under war or emergency state conditions. An emergency (not a state) has been introduced in Ukraine today, which does not provide grounds for restricting constitutional rights. The Constitutional Court has considered this issue. The Constitutional Court of Ukraine has emphasized that restriction of constitutional rights and freedoms of a man and citizen is possible in cases specified by the Constitution of Ukraine. Such a restriction may be established only by law by the Verkhovna Rada of Ukraine as the only legislative body in Ukraine. The establishment of such a restriction by a bylaw contradicts Articles 1, 3, 6, 8, 19, 64 of the Constitution of Ukraine [23].

The introduction of such special regimes as quarantine or emergency in the state involves restricting fundamental human rights, including the right to peaceful assembly. Therefore, when implementing them, it is necessary to adhere to the relevant constitutional norms strictly.

Because of those mentioned above, the legal regulation of the mechanism for exercising the right to peaceful assembly remains more than relevant. As it can be seen, some bylaws adopted in different years contradict each other, do not meet the requirements of the Constitution or the challenges of modern public life. Today, Ukraine has dozens of laws related to the right to peaceful assembly. However, they do not regulate the provision of the right to peaceful assembly by the Constitution of Ukraine.

Thus, the Civil Code of Ukraine determines the right of individuals to freely gather for peaceful 
assemblies, conferences, meetings, festivals, etc. The court may impose restrictions on exercising the right to peaceful assembly by the law [26]. As it has already been mentioned, the provisions of the Law of Ukraine "On Local Self-Government" are designed to regulate the right of citizens to a general meeting to resolve local issues. The delegated powers of the executive bodies of the village, settlement, town councils include resolving the issues of holding meetings, rallies, manifestations and demonstrations, sports events, entertainment and other mass events; exercising control over the provision of public order during their implementation. However, as of today, the law gives local executive bodies almost no powers in peaceful assemblies. The only power of local authorities arising from Article 39 of the Constitution of Ukraine is the right to apply to the court to prohibit or restrict the right to peaceful assembly immediately after receiving the relevant notice [6].

Specific laws set limits on the place, time, subject matter, and range of individuals who may participate in peaceful assemblies. In particular, certain restrictions are set in the election legislation regarding the time and subject of holding peaceful assemblies. Thus, the Laws of Ukraine "On Elections of People's Deputies of Ukraine", "On Elections of the President of Ukraine", "On Local Elections" stipulate that holding peaceful assemblies is one of the forms of campaigning. The provisions of these laws prohibit the holding of peaceful assemblies to campaign on issues that are the subject of the will of voters in the elections during the so-called "day of silence" on the election eve and day, respectively. According to M. Sereda, "such regulation is at least controversial given the provisions of the Constitution of Ukraine concerning the right to freedom of speech and the right to freedom of peaceful assembly. After all, the Constitution does not provide for other grounds for restriction than those established in the interests of national security and public order to prevent riots or crimes, to protect public health or to protect the rights and freedoms of others. Thus, there arises an issue whether peaceful assemblies aimed to agitate in any place pose a threat to national security or public order" [24, p.139-140].

Contrary to Article 39 of the Constitution of Ukraine, which establishes the informative nature of peaceful assemblies, the Law of Ukraine "On Freedom of Conscience and Religious Organizations" provides for the permission of local au- thorities to hold public worships, religious rites, ceremonies and processions outside religious buildings. According to Article 11 of the European Convention on Human Rights and the caselaw of the European Court of Human Rights, guarantees of the right to freedom of peaceful assembly should be applied to these relations. The permissive nature of public worship, religious rites, ceremonies and processions outside religious or other buildings and adjacent areas must be changed into an informative one [5].

The High Council of Justice also emphasizes the need to adopt a particular law. The Advisory Opinion of the High Council of Justice states that at the legislative level, there should be a detailed mechanism that regulates holding of peaceful assemblies, rallies, demonstrations, pickets, other similar or analogical actions near court buildings, advance notice of such events with mandatory identification of the body that must be notified of their holding, permission to hold relevant actions, etc. Such a subject of regulation should be regulated in a particular law, which must comply with the basic principles of the Constitution of Ukraine and the Convention and take into account the rules set by other legislative acts [10].

It is also necessary to amend the Law of Ukraine "On Court Fees" regarding the exemption from court fees in cases of restriction of freedom of peaceful assembly, removal of obstacles and prohibition of interference with the exercise of freedom of peaceful assembly. According to experts, the problems with the payment of court fees are caused by the very short deadlines for filing a lawsuit or complaint. Therefore, by analogy with some electoral disputes, it is necessary to remove the obligation of the plaintiff or appellant to pay court fees in such cases to ensure that they have the opportunity to go to court promptly [7].

Particular issues of exercising the right to peaceful assembly are covered in the Decision of the Constitutional Court of Ukraine No 1-30/2001 in the case of early notification of peaceful assemblies initiated by the Ministry of Internal Affairs of Ukraine on the official interpretation of Part 1 of Article 39 of the Constitution of Ukraine about the early notification of executive bodies or local self-government bodies about meetings, rallies, marches and demonstrations [22].

Peculiarities of proceedings in cases of administrative claims of subjects of power concerning the restrictions on the exercise of the right to peaceful assembly are defined in the Code of 
Administrative Procedure of Ukraine. A new version of the Code, which came into force on 15 December 2017, is favourable for the organizers of peaceful assemblies. It has significantly complicated the procedure for restricting the right to peaceful assembly. Thus, the law has established the obligation of the plaintiff (authority) to take measures to acquaint the organizers of peaceful assemblies with the content and annexes to the statement of claim on the establishment of restrictions on peaceful assemblies, and it has obliged the authority to send its representative for personal participation in the case. In addition, according to the law, the court must leave without considering the statement of claim for restriction of the right to peaceful assembly if it was received later than 24 hours before the scheduled date. Thus, the law prevented the previously common damaging practice when courts regularly considered cases of restriction of peaceful assemblies without the participation of the parties (often, the organizers of peaceful assemblies did not even know about the ban hearing) and prohibited them from taking place several hours before their scheduled start. Another novelty of the Code is that in deciding in favour of restricting the right to peaceful assembly, the court must apply the least onerous method of such restriction, which meets the goals stated by the authority. The law also provided for reduced deadlines and a procedure for appealing a court decision restricting the right to peaceful assembly.

The Procedural Law also determines the peculiarities of proceedings in lawsuits to eliminate restrictions on the exercise of the right to peaceful assembly (Article 281 of the Criminal Procedure Code of Ukraine). Responsibility for violating the order of organization and holding meetings, rallies, street marches and demonstrations is established by Article 185-1 of the Code of Ukraine on Administrative Offenses [24, p. 186].

An essential source of the right to peaceful assembly in Ukraine is the case law of the European Court of Human Rights. According to R. Melnyk, "in the decisions of the Court, you can find answers to almost all questions that arise in domestic law enforcement practice aimed at ensuring the exercise by individuals of the right to freedom of peaceful assembly" [6, p. 10].

Thus, current laws regulate a minimal area of legal relations related to peaceful assemblies. In particular, at the legislative level, there have not been defined the terms and form of prior notification of peaceful assemblies (except for the terms of notification of the meeting organized by the person who leads the strike) and the state's positive obligations to hold peaceful assemblies. There is no possibility to hold meetings without notice (so-called "spontaneous" meetings), etc. Some laws are also debatable about the degree of their compliance with the Constitution of Ukraine.

A systematic analysis of the provisions of Articles 39 and 62 of the Constitution of Ukraine gives grounds to conclude that the presence in the text of the Constitution of the statements "in the manner prescribed by law", "in cases prescribed by law", "established by law" and others is a procedural aspect of its direct effect on the possibility of detailing the initial provisions to regulate the procedure for their implementation.

Thus, the direct effect of the Constitution of Ukraine in the procedural aspect is its legal property, which is based on the possibility to detail its substantive provisions to establish the procedure for their implementation, and it is ensured by adopting special laws provided exclusively in the Constitution of Ukraine.

In a democratic state governed by the rule of law, a different procedure for holding peaceful assemblies cannot be established depending on their organizers and participants, purpose and place, form, etc. Thus, Article 24 of the Constitution of Ukraine in conjunction with Part 1 of Article 35, Part 1 of Article 39 obliges the state to create uniform legal mechanisms governing the conduct of citizens, public or religious organizations, other subjects of the right for peaceful public meetings of religious and non-religious nature. Such meetings should be held after prior notification of the executive authorities or local selfgovernment bodies by the relevant legal entities.

It should be noted that the adoption of such a law has been repeatedly initiated at the legislative level. One of the latest draft laws, "On Guarantees of Freedom of Peaceful Assembly", was submitted to the Verkhovna Rada of Ukraine and was registered on 28 September 2019, but it was not adopted. The draft law was aimed to create conditions for the free exercise of freedom of peaceful assembly in Ukraine by Article 39 of the Constitution of Ukraine, Article 21 of the International Covenant on Civil and Political Rights, Article 15 of the Convention on the Rights of the Child, Article 11 of the Convention for the Protection of 
Human Rights and Fundamental Freedoms, Guidelines on Freedom of Peaceful Assembly of the OSCE Office for Democratic Institutions and Human Rights and the Venice Commission of the Council of Europe.

The draft law defined a peaceful assembly as a public event held in a public place peacefully, without weapons in the form of a meeting, rally, demonstration, march or any combination of these forms or in other forms not prohibited by law to express a personal, civil or political position on any issues [18].

The draft law could address some issues, including notification of public authorities and local governments of a peaceful assembly so that they can adequately fulfil their positive obligations to ensure the exercise of the right to freedom of peaceful assembly; definition of clear positive obligations of state authorities and local governments to ensure the exercise of the right to freedom of peaceful assembly; establishment of clear and exclusive grounds and methods for restricting the freedom of peaceful assembly in the interests protected by Part 1 of Article 11 of the Constitution of Ukraine; guarantee of the right to simultaneous peaceful assemblies, including counter-assemblies, to spontaneous peaceful assemblies, as required by Ukraine's international obligations; creation of judicial guarantees for the protection of freedom of peaceful assembly; bringing the provisions of specific laws in line with the Constitution of Ukraine and this Law.

If passed, the draft law would enable to overcome the practice of judicial prohibitions of peaceful assemblies without legally defined grounds, as well as the practice of bringing to administrative responsibility of organizers and participants of peaceful assemblies who have not committed offences; reorient public authorities and local governments to respect for freedom of peaceful assembly and assistance in its implementation.

In our opinion, the need to adopt a special law meets the requirements of paragraph 1, Part 1 of Article 92 of the Constitution of Ukraine. The rights, freedoms of a man and citizen, and guarantees of these rights are determined exclusively by law. In addition, the right to freedom of peaceful assembly may be restricted only by the law (Part 2 of Article 39). In addition, determination of specific terms of early notification is subject to legislative regulation (Part 1 of Article 39 of the Constitution of Ukraine, paragraph 1 of the oper- ative part of the Decision of the Constitutional Court of Ukraine in the case of early notification of peaceful assemblies of 19 April 2001) [22].

The world community has repeatedly drawn attention to the need for urgent concrete reforms. The European Court of Human Rights stressed the need for urgent concrete reforms in Ukrainian law and administrative practice to bring these laws and practices in line with Articles 7 and 11 of the Convention (paragraph 95 of the Judgment of the European Court of Human Rights in the case of "Shmushkovych v. Ukraine" of 14 November 2013 and in the case of "Verentsov v. Ukraine of 11 April 2013) [19, 20].

The need to adopt such a law is also mentioned in Recommendation 97.123 of the UN Universal Periodic Review "to implement legislation on the right to freedom of assembly by the standards of Article 21 of the International Covenant on Civil and Political Rights", which Ukraine has unconditionally adopted.

It is also necessary to amend the Law of Ukraine "On Local Self-Government in Ukraine" to clarify the powers of the relevant bodies to ensure the freedom of peaceful assembly; Law of Ukraine "On the Capital of Ukraine - the Hero City of Kyiv" on the exclusion of the possibility of regulating the procedure for exercising the right to freedom of peaceful assembly by the local bylaw; the Law of Ukraine "On the Procedure for Resolving Collective Labor Disputes (Conflicts)" on the removal of provisions that are subject to the regulation of the legislation on freedom of peaceful assembly, and not labour legislation.

\section{CONCLUSIONS}

Changes in Ukrainian society reveal active civil position and desire of citizens to participate in governing the state and solve social problems through peaceful assemblies. A special law must support the constitutional right to peaceful assembly. Negative consequences of the absence of a particular law that guarantees the constitutional right of Ukrainian citizens to peaceful assembly and the gaps and shortcomings of some current bylaws provoke sound criticism from the public, experts and scholars, and the international community. Even a tiny number of norms enshrined in regulations are inconsistent and do not comply with constitutional norms. They do not regulate the right to the peaceful assembly at the appropriate level. In a special law on the regulation of 
the right to peaceful assembly, it is necessary to establish terminology related to the right to peaceful assembly, to define the concept of peaceful assembly, their types (rally, demonstration, picket, protest, etc.); to settle the issue of the optimal terms of notification of the holding and place of a peaceful assembly; to determine the grounds for restrictions on holding peaceful assemblies; rights and responsibilities of organizers and participants of peaceful assemblies, pow- ers of authorities and local self-government, internal affairs bodies, etc.

Gaps and shortcomings in the current normative acts that regulate the right to peaceful assembly need to be addressed as soon as possible to bring national legislation into line with international standards in the field of fundamental human and civil rights.

\section{REFERENCES}

1. McBride, J. (2005). Freedom of Association. The Essentials of Human Rights. London: Hodder Arnold.

2. Slovnyk ukrainskoi movy. (2021). About. Retrieved 14 February, 2021, from http://sum.in.ua (in Ukrainian).

3. Vlasenko, 0. (2011). Konstytutsiine pravo hromadian na svobodu zboriv, mitynhiv, pokhodiv $i$ demonstratsii [Constitutional right of citizens to freedom of assembly, rallies, marches and demonstrations] (Doctoral thesis); National Academy of Internal Affairs. Kyiv (in Ukrainian)

4. United Nations. (2020). Report on the Human Rights Situation in Ukraine. 16.02-31.07.2020. Retrieved from https://www.ohchr.org/Documents/Countries/UA/30thReportUkraine_EN.pdf

5. Pro svobodu sovisti ta relihiini orhanizatsii [On Freedom of Conscience and Religious Organizations] (Ukraine), 23.04.1991, No 987-XII. Retrieved 5 February, 2021, from https://zakon.rada.gov.ua/laws/show/987-12\#Text (in Ukrainian).

6. Pro mistseve samovriaduvannia v Ukraini [On Local Self-Government in Ukraine] (Ukraine), 21.05.1997, No 280/97-BP. Retrieved 5 February, 2021, from https://zakon.rada.gov.ua/laws/show/280/97-\%D0\%B2\%D1\%80\#Text (in Ukrainian).

7. Pro sudovyi zbir [On Court Fees] (Ukraine), 08.07.2011, No 3674-VI. Retrieved 7 February, 2021, from https://zakon.rada.gov.ua/laws/show/3674-17 (in Ukrainian).

8. United Nations. (2012, 10 April). Report of the United Nations High Commissioner for Human Rights on the outcome of the seminar addressing the adverse impacts of climate change on the full enjoyment of human rights. Retrieved from http://www.ohchr.org/Documents/HRBodies/HRCouncil/RegularSession/Session20/A-HRC20-7_en.pdf

9. Konstytutsiia Ukrainy [The Constitution of Ukraine] (Ukraine), 28 June 1996. Retrieved 5 February, 2021, from https://zakon.rada.gov.ua/laws/show/254\%D0\%BA/96-\%D0\%B2\%D1\%80 (in Ukrainian)

10. High Council of Justice. (2020, 27 October). Konsultatyvnyi vysnovok shchodo zakonoproiektu № 3291 [Advisory opinion on the draft law No 3291]. Retreieved 10 February, 2021, from https://hcj.gov.ua/doc/doc/4526 (in Ukrainian).

11. Melnyk, R. S. (2014). Analiz proektiv zakoniv Ukrainy pro myrni zibrannia kriz pryzmu yevropeiskoi yurydychnoi tradytsii [Analysis of draft laws of Ukraine on peaceful assemblies through the prism of the European legal tradition]. Zhurnal skhidnoievropeiskoho prava, 4, 4-15 (in Ukrainian).

12. Melnyk, R. S. (2015). Pravo na svobodu myrnykh zibran: teoriia i praktyka [The right to freedom of peaceful assembly: theory and practice]. Kyiv: VAITE (in Ukrainian).

13. Nesterovych, V. F. (2018). Problemy konstytutsiino-pravovoho rehuliuvannia provedennia myrnykh zibran hromadian v Ukraini [Problems of constitutional and legal regulation of peaceful assemblies of citizens in Ukraine]. Visnyk Luhanskoho derzhavnoho universytetu vnutrishnikh sprav imeni E.O. Didorenka, 2(82), 48-59 (in Ukrainian).

14. Onyshchenko, S. M. (2019). Administratyvno-pravove zabezpechennia prava na myrni zibrannia [Administrative and legal support of the right to peaceful assembly] (Doctoral dissertation); State Research Institute of the Ministry of Internal Affairs of Ukraine. Kyiv (in Ukrainian). 
15. Pohorilko, V. F., \& Fedorenko, V. L. (2009). Referendne pravo Ukrainy [Referendum Law of Ukraine]. Kyiv: Lira (in Ukrainian)

16. Radchenko, O. V. (Ed.). (2010). Politychna abetka : materialy dlia praktychnoho vykorystannia [Political alphabet: materials for practical use] (8th ed.). Kharkiv: DokNaukDerzhUpr (in Ukrainian)

17. Pro zapobihannia poshyrenniu na terytorii Ukrainy koronavirusu COVID-19 [On Prevention of the Spread of COVID-19 in Ukraine] (Ukraine), 11.03.2020, No 211. Retreieved 10 February, 2021, from https://zakon.rada.gov.ua/laws/show/211-2020-\%D0\%BF\#Text (in Ukrainian).

18. Pro harantii svobody myrnykh zibran [Draft Law on Guarantees of Freedom of Peaceful Assembly] (Ukraine), Retreieved 10 February, 2021, from

http://w1.c1.rada.gov.ua/pls/zweb2/webproc4_1?pf3511=66509 (in Ukrainian).

19. European Court of Human Rights. (2013, 11 April). Case of Verentsov vs Ukraine (No 20372/11).

Retrieved from https://zakon.rada.gov.ua/laws/show/974_945\#Text (in Ukrainian).

20. European Court of Human Rights. (2013, 14 November). Case of Shmushkovych vs Ukraine (No 3276/10). Retrieved from https://zakon.rada.gov.ua/laws/show/974_990\#Text (in Ukrainian).

21. Constitutional Court of Ukraine. (2016, 8 September). Shchodo vidpovidnosti Konstytutsii Ukrainy (konstytutsiinosti) polozhen chastyny piatoi statti 21 Zakonu Ukrainy "Pro svobodu sovisti ta relihiini orhanizatsii» (sprava pro zavchasne spovishchennia pro provedennia publichnykh bohosluzhin, relihiinykh obriadiv, tseremonii ta protsesii] [On the constitutionality of the provisions of Part 5 of Article 21 of the Law of Ukraine "On Freedom of Conscience and Religious Organizations" (case of early notification of public worship services, religious rites, ceremonies and processions)]. Retrieved from https://zakon.rada.gov.ua/laws/show/v006p710-16\#Text (in Ukrainian).

22. Constitutional Court of Ukraine. (2001, 19 April). Shchodo ofitsiinoho tlumachennia polozhennia chastyny pershoi statti 39 Konstytutsii Ukrainy pro zavchasne spovishchennia orhaniv vykonavchoi vlady chy orhaniv mistsevoho samovriaduvannia pro provedennia zboriv, mitynhiv, pokhodiv $i$ demonstratsii (sprava shchodo zavchasnoho spovishchennia pro myrni zibrannia) [On the official interpretation of the provisions of Part 1 of Article 39 of the Constitution of Ukraine on early notification of executive or local government bodies on meetings, rallies, marches and demonstrations]. Retrieved from http://zakon4.rada.gov.ua/laws/show/v004p710-01 (in Ukraine).

23. Constitutional Court of Ukraine. (2020, 28 August). Shchodo vidpovidnosti Konstytutsii Ukrainy (konstytutsiinosti) okremykh polozhen postanovy Kabinetu Ministriv Ukrainy "Pro vstanovlennia karantynu z metoiu zapobihannia poshyrenniu na terytorii Ukrainy hostroi respiratornoi khvoroby COVID-19, sprychynenoi koronavirusom SARS-CoV-2, ta etapiv poslablennia protyepidemichnykh zakhodiv», polozhen chastyn pershoi, tretoi statti 29 Zakonu Ukrainy "Pro Derzhavnyi biudzhet Ukrainy na 2020 rik", abzatsu deviatoho punktu 2 rozdilu II "Prykintsevi polozhennia" Zakonu Ukrainy "Pro vnesennia zmin do Zakonu Ukrainy "Pro Derzhavnyi biudzhet Ukrainy na 2020 rik" [On the constitutional petition of the Supreme Court on the constitutionality of certain provisions of the resolution of the Cabinet of Ministers of Ukraine "On quarantine to prevent the spread of acute respiratory disease COVID-19 caused by coronavirus V SARS-2, and stages of mitigation of anti-epidemic measures", provisions of Parts 1 , 3 of Article 29 of the Law of Ukraine "On State Budget of Ukraine 2020", paragraph 9 of Paragraph 2 of Chapter II "Final Provisions" of the Law of Ukraine "On Amendments to the Law of Ukraine "On State Budget of Ukraine 2020]. Retrieved from https://zakon.rada.gov.ua/laws/show/v010p710-20\#Text (in Ukrainian).

24. Sereda, M. L. (2019). Pravo na myrni zibrannia: teoretychni, praktychni ta porivnialno-pravovi aspekty [The right to peaceful assembly: theoretical, practical and comparative legal aspects] (Doctoral dissertation); Kyiv-Mohyla Academy. Kyiv (in Ukrainian).

25. Slovnyk ukrainskoi movy. (2021). Fleshmob [Flashmob]. Retrieved from https://slovnyk.ua/index.php?swrd=\%D0\%A4\%D0\%9B\%D0\%95\%D0\%A8\%D0\%9C\%D0\%9E \%D0\%91 (in Ukrainian). 
26. Tsyvilnyi kodeks Ukrainy [The Civil Code of Ukraine] (Ukraine), 16.01.2003, No 435-IV. Retrieved 10 February, 2021, from https://zakon.rada.gov.ua/laws/show/435-15\#Text (in Ukrainian)

27. Shevchenko, A. Y., Denisova, M. M., \& Denisova, O. S. (2011). Realizatsiia konstytutsiinoho prava na myrni zibrannia $v$ Ukraini [Realization of the constitutional right to peaceful assembly in Ukraine]. Donetsk: Knowledge.

28. Shemshuchenko, Y. S. (Ed.). (2004). Yurydychna entsyklopediia [Legal Encyclopedia]. Kyiv: Ukrainska entsyklopediia (in Ukrainian).

29. Yarmol, L. V. (2016). Pravo na myrni zibrannia: do utochnennia zahalnoteoretychnoi kharakterystyky [The right to peaceful assembly: on the clarification of the general theoretical characteristics]. Visnyk Natsionalnoho universytetu "Lvivska politekhnika". Seriia: Yurydychni nauky, 850, 331-337 (in Ukrainian). 